\title{
On the 91/17 pattern in the brackish ichnofabric
}

\section{Ery Arifullah}

Human Resources Development Agency, East Kalimantan Government

\begin{abstract}
From earlier research, I have identified what ichnotaxa dominate each ichnofabric unit and how many ichnotaxa are taking up a share of the total observed ichnofabric units. The contribution of this paper is the $91 / 17$ pattern. The point of this pattern is that only $17 \%$ ichnotaxa (6 of 34 ichnotaxa) had $91 \%$ of the total ichnofabric units that were observed. In addition, the six ichnotaxa tend to be more monospecific. These are the most effective strategies for the animal to survive by constructing the most essential structures. These strategies are common in brackish paleoecology in the fluvial-marine transition zone.
\end{abstract}

Keywords: ichnofabric, ichnofossils, fluvial-marine transition, Samarinda, Kutei basin 


\section{INTRODUCTION}

The study area is a fluvial-marine transition zone depositional system (Bachtiar, 2004; Arifullah, 2005). Most authors interpreted it based only on the sedimentological evidence, although ichnofossil is relatively easy to be observed in the outcrops. This lack of evidence uses, caused poor understanding of the paleo fluvialmarine transition zone in the area.

In terms of geomorphic units, ichnofossil is an indirect proxy for the fluvial-marine transition zone. However, it is a direct proxy of paleoecology (Arifullah, 2019). The common paleoecology in the study area is brackish (Bachtiar, 2004). In this place the temperature, salinity and turbidity of water is a fluctuating and biologically stressed environment (Dalrymple and Choi, 2007). Thus, I hypothesize that only a few types of ichnofossil will dominate and emerge as monospecific variants.

\section{METHODOLOGY}

I had observed 640 ichnofabric units in 20 outcrops located in Samarinda area, Kutai Basin, East Kalimantan, Indonesia (Figure 1). The outcrops are also part of the Serravallian-Tortonian interval. General morphology (in three dimensions), orientation to bedding surface and branching, burrow fill and burrow lining were scrutinized. This approach is a taxonomic requirement for ichnofossil to address either ichnotaxon or ichnotaxa (Arifullah et al., 2016).
The predominant ichnotaxon in ichnofabric units is the basis for the naming of the ichnofossil association. An ichnotaxon is dominant if its present is over $50 \%$ than other ichnotaxon/ichnotaxa in ichnofabric units (Pickerill and Narbonne, 1995). I put the code to the ichnofabric unit. Each code describes outcrop location, dominant ichnotaxon and secondary ichnotaxon (see Arifullah, 2019). With codification, I calculated what ichnotaxa dominates and know the tendency of those ichnofossil associations to appear in ichnofabric units, whether they tend to be monospecific or polyspecific. I did that by statistical analysis. The Pareto histogram was used to visualize the probability of ichnofossil association from highest to lowest. Another histogram is presented to compare between monospecific and polyspecific trends of the ichnofabric unit.

\section{RESULTS}

Thirty-four ichnotaxa had been identified and twenty of them are dominant in the ichnofabric unit. Based on the Pareto histogram, there are only six ichnotaxa that stand out (Figure 2), which is about $17 \%$ of the total identified ichnotaxa. I call it the "elite ichnofossil" (Arifullah et al., 2020). There are Ophiomorpha (27\%), Skolithos (23\%), Paleophycus (13\%), Planolites (10\%), Thalassinoides (10\%) and Chondrites (8\%) with a cumulative frequency of $91.09 \%$. Thus, the actual pattern is $91 / 17$. It means that only a small portion of ichnotaxa obtains a major share of the total ichnofabric units. To understand the ichnotaxa, 


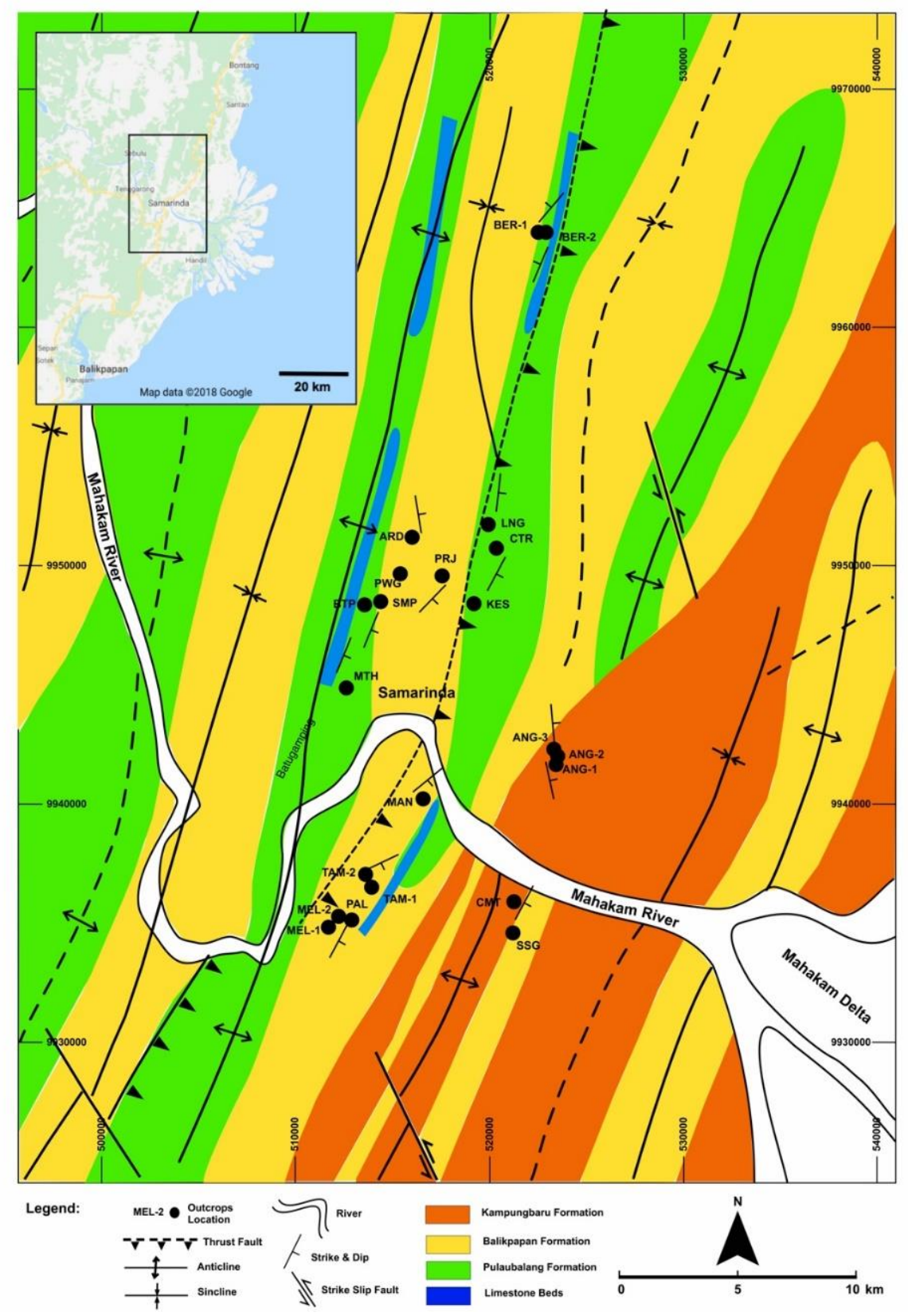

Figure 1. The geological map of Samarinda Area (modified after Supriatna, 1995).

brief descriptions of the ichnotaxa are presented in the following paragraphs.

Ophiomorpha can show structures that are either tunnels, shafts, or both (complex). It appears as full relief and/or epirelief. Its burrow lining is strengthened by lithic fragments and pellets (Figure 3A). Since burrow fill of
Ophiomorpha shows passive fill and/or meniscate backfill structure, all Ophiomorpha can be found in fine to coarse-grained sandstones.

Skolithos is a cylindrical shaft burrow. It means vertical orientation to the bedding surface (Figure 3B). It can show straight or curved-like shaft 
morphology. No branches are found. It appears as full relief and/or epirelief. There is no indication of burrow lining. Skolithos can be spotted in both mudstone and sandstone.

Paleophycus is a cylindrical tunnel burrow (Figure 3C). It means horizontal orientation to the bedding surface and might present as straight or curved-like. No branches shown. It turns up as full and/or epirelief and always displays thin burrow lining. The burrow fill shows passive fill structure. Paleophycus is often found in fine to medium-grained sandstones.

Planolites is a cylindrical tunnel burrow that shows sub horizontal to horizontal orientation to the bedding surface without branching. (Figure 3D). Planolites do not have burrow lining. Its burrow fill displays active fill. In general, its color contrasts with the surrounding sediment. Planolites can be discovered in mudstone or muddy sandstone. Sometimes Planolites' tunnel is mistaken for Chondrites, however Planolites does not have a

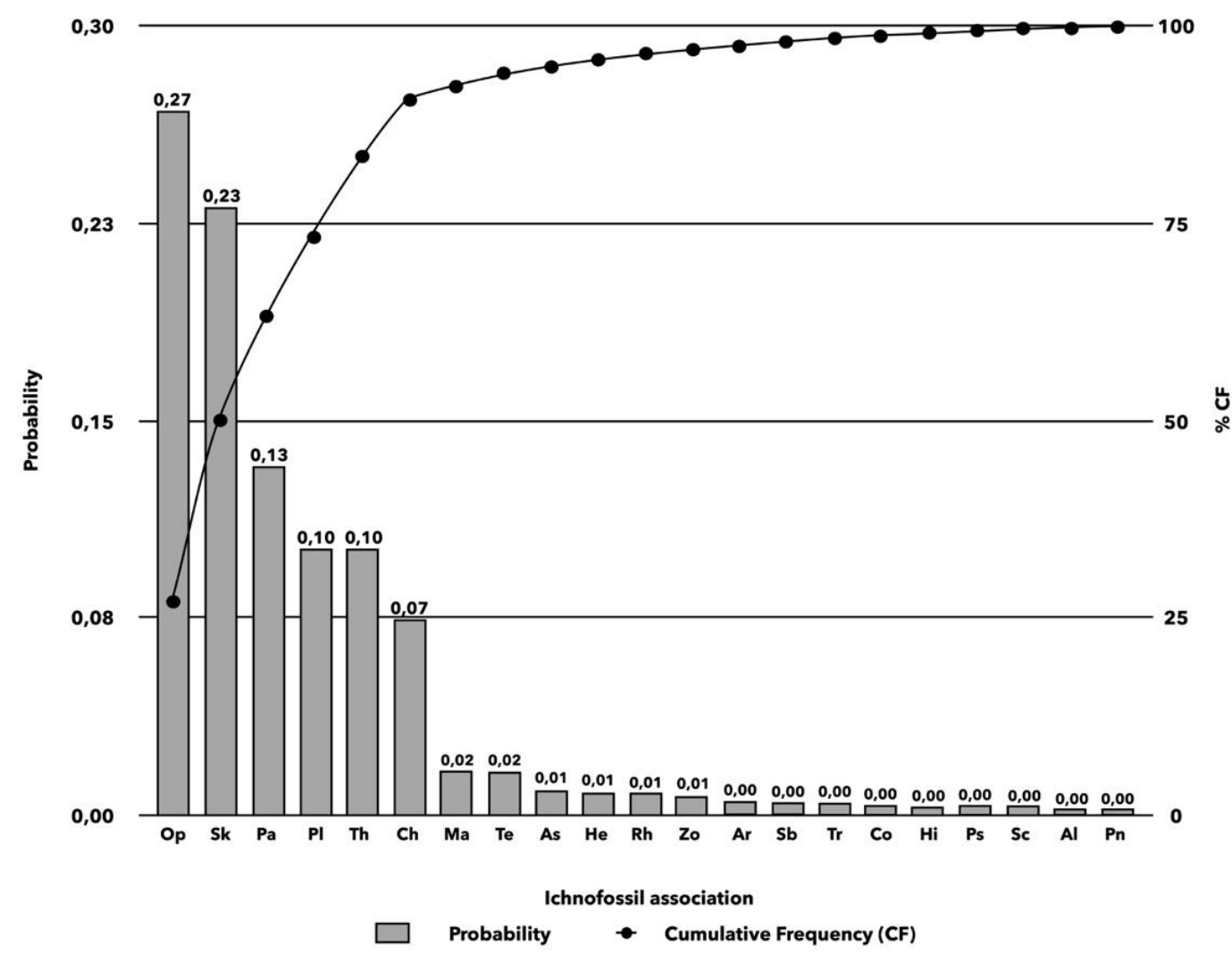

Figure 2. The Pareto histogram of the ichnofossil, there are only six ichnotaxa that stand out (after Arifullah, 2019). Notes: Op: Ophiomorpha, Sk: Skolithos, Pa:

Paleophycus, Th: Thalassinoides, Pl: Planolites, Ch: Chondrites, Ma: Macaronichnus, Te: Teichichnus, As: Asterosoma, He: Helmintoidinichnites, Rh: Rhizocorallium, Zo: Zoophycos, Ar: Arenicolites, Sb: Schaubcylindrichnus, Tr: trackway, Co: Conichnus, Ps: Psilonichnus, Sc: Scolicia, Al: Alcyonidiopsis, Pn: Phycosiphon. 


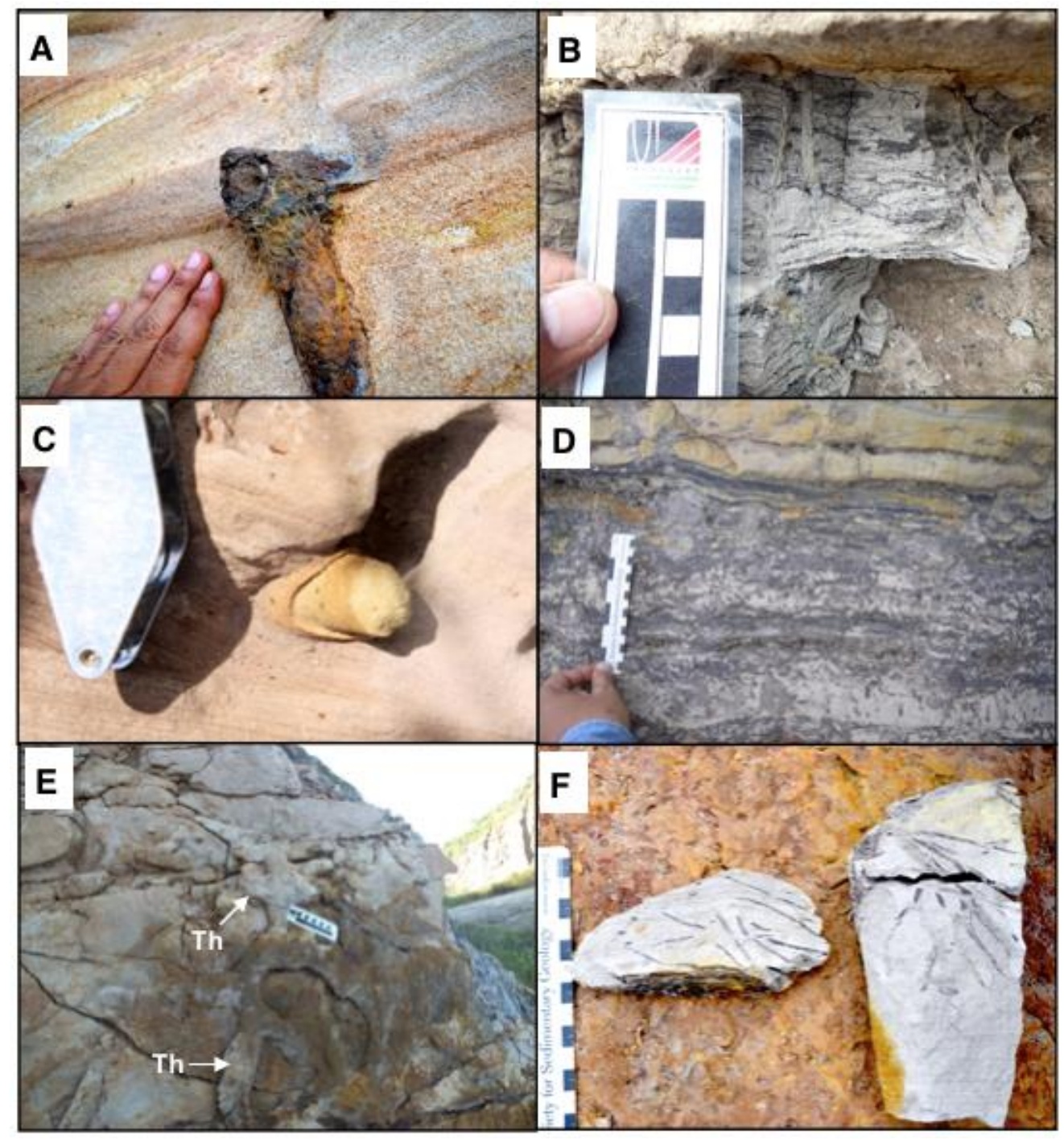

Figure 3. The six ichnotaxa (elite ichnofossil): A. Ophiomorpha, B. Skolithos, C. Paleophycus, D. Planolites, E. Thalassinoides, F. Chondrites (after Arifullah, 2019).

shaft like Chondrites has. Therefore, research on something similar to Planolites or Chondrites should be done.

Thalassinoides is a complex structure that shows a gallery (Figure 3E). It appears as full and/or epirelief. The burrow fill of Thalassionoides shows meniscate backfill and passive fill. The morphology may be similar to Ophiomorpha, but the burrow lining is in stark contrast. Thalassinoides have smooth burrow lining and often appear in mudstone or muddy sandstone.

Chondrites is a complex structure that shows similarities to the morphology of the roots (Figure 3F). Therefore, it must have exposed the shaft and tunnel. It can turn up as full relief and/or epirelief. In epirelief feature, Chondrites shows its tunnel structure only. Chondrites are often found in both mudstone and fine-grained sandstone. 


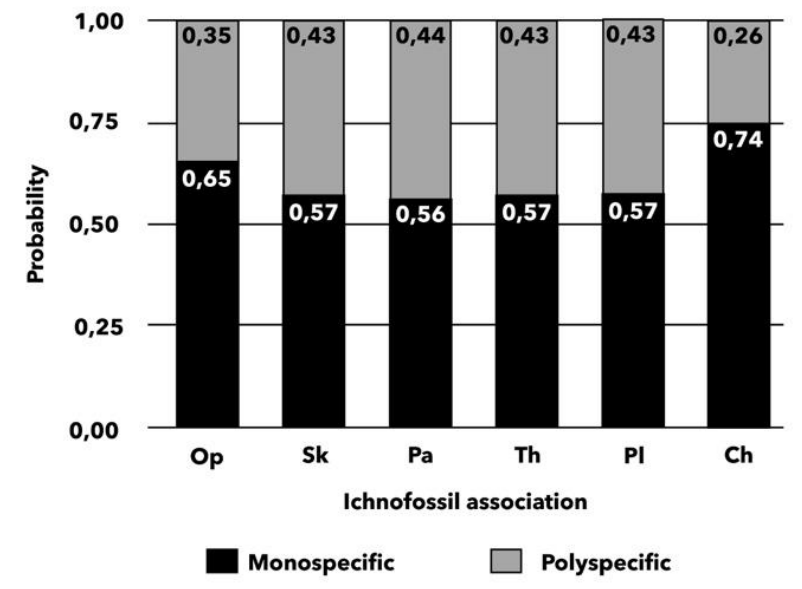

Observations on 640 ichnofabric units show that Ophimorpha, Skolithos, Paleophycus, Planolites, Thalassinoides and Chondrites have a more dominant performance as monospecific variants than polyspecific (Figure 4). It means that elite ichnotaxa tend to perform as single ichnotaxon in ichnofabric units.

\section{DISCUSSION AND CONCLUSION}

Based on the complexity of the elite ichnofossil, Ophiomorpha, Thalassinoides and Chondrites are
Figure 4. The histogram showing the trend whether the six ichnotaxa tends to develop as a monospecific or polyspecific variant (after Arifullah, 2019). Notes: Op: Ophiomorpha, Sk:

Skolithos, Pa: Paleophycus, Th:

Thalassinoides, Pl: Planolites, Ch: Chondrites permanent structures, while Skolithos, Palaephycus and Planolites are incidental structures. Permanent structures imply longer window colonization than incidental ones (see Pollard et al., 1993; Taylor et al., 2003). Furthermore, paleoecological significance of the elite ichnofossil is presented in Table 1. It shows how the animal gets its food, substrate stability, the richness of organic matter, sedimentological processes and water turbidity.

Table 1. Paleoecological significance of ichnofossil association (after Arifullah, 2019)

\begin{tabular}{|c|c|c|c|}
\hline Association & Behavior & Paleoecology & References \\
\hline Ophiomorpha & $\begin{array}{l}\text { Domichnia, } \\
\text { fodonichnia }\end{array}$ & 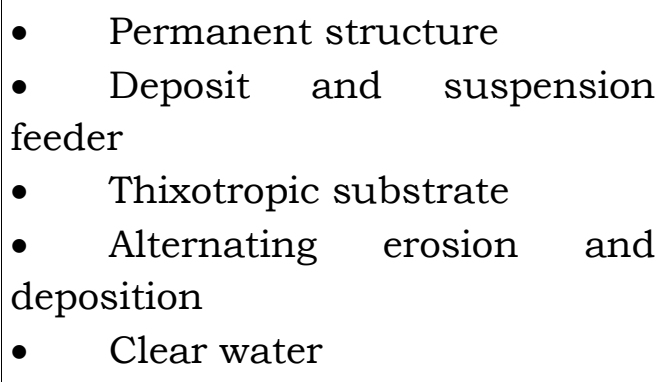 & $\begin{array}{l}\text { (Bromley, 1996; } \\
\text { Howard, } \\
\begin{array}{l}\text { Pollard } \\
1993)\end{array} \text { et al., }\end{array}$ \\
\hline Skolithos & Domichnia & $\begin{array}{l}\text { - Incidental structure } \\
\text { - Suspension feeder }\end{array}$ & $\begin{array}{l}\text { (Rhoads and Young, } \\
\text { 1970; Miller, 2007) }\end{array}$ \\
\hline
\end{tabular}




\begin{tabular}{|c|c|c|c|}
\hline Association & Behavior & Paleoecology & References \\
\hline & & - Clean water & \\
\hline Paleophycus & Domichnia & $\begin{array}{l}\text { - Incidental structure. } \\
\text { - Suspension feeder. } \\
\text { - Thixotropic substrate. } \\
\text { - Clean water. }\end{array}$ & $\begin{array}{l}\text { (Pemberton et al., } \\
2001)\end{array}$ \\
\hline Planolites & $\begin{array}{l}\text { Fodonichnia, } \\
\text { paschichnia }\end{array}$ & $\begin{array}{l}\text { - Incidental structure. } \\
\text { - Detritus-deposit feeder. } \\
\text { - Dilatancy substrate. } \\
\text { - Cloudy water. } \\
\text { - Anoxic. }\end{array}$ & $\begin{array}{|lr|}\text { Bromley, } & \text { 1996; } \\
\text { Pemberton } & \text { and } \\
\text { Frey, 1982) } & \end{array}$ \\
\hline Thalassinoides & $\begin{array}{l}\text { Domichnia, } \\
\text { fodonichnia }\end{array}$ & $\begin{array}{l}\text { - Permanent structure. } \\
\text { - Deposit and suspension feeder. } \\
\text { - Dilatancy substrate. }\end{array}$ & $\begin{array}{l}\text { (Bromley, 1967; } \\
\text { Bromley, 1996) }\end{array}$ \\
\hline Chondrites & Agrichnia & $\begin{array}{l}\text { - Permanent structure. } \\
\text { - Deposit feeder. } \\
\text { - Dilatancy substrate. }\end{array}$ & (Kotake, 1991) \\
\hline
\end{tabular}

In this ichnological study, the $91 / 17$ pattern indicates that some ichnotaxa are very effective at making less variety of ichnotaxa. To survive, animals construct ichnotaxa by considering factors such as substrate type and access to food. It is the optimal effort to deal with that biological stress environment such as unstable conditions that are always repetitive, unpredictable and possibly reworking existing communities. I think this condition is an established indicator of brackish paleoecology. This interpretation is consistent with the result of benthic studies of Bachtiar (2004).

Brackish paleoecology can occur in any depositional environment located in the fluvial-marine transition zone (Dalrymple and Choi, 2007) which includes deltas, estuaries, tidal flats, stranded plains (Boyd et al., 1992). Therefore, elite ichnofossils cannot be used as an indicator for a specific depositional environment in the fluvial-marine transition zone. Other parameters of ichnofossil data should be observed and their distribution should be mapped.

\section{ACKNOWLEDGEMENT}

Funding for this study was provided through a scholarship from the East Kalimantan Government and Chevron to Ery Arifullah while studying for a 
doctoral program at the Department of Geology, Institut Teknologi Bandung.

\section{REFERENCES}

Arifullah, E., 2005. Karakteristik ichnologi dan sistem pengendapan delta-studi kasus: Delta Mahakam modern dan Miosen, Cekungan Kutai, Kalimantan Timur [Thesis]. Institut Teknologi Bandung. (Text in Indonesia)

Arifullah, E., Chandra, A., Setiaji, Romy. A., Yahdi, Z., Aswan and Djuhaeni, 2016. Perkembangan penelitian iknologi di Indonesia. Seminar Nasional Kebumian Ke-9: Peran Penelitian Ilmu Kebumian Dalam Pemberdayaan Masyarakat, pp. 700-713.

Arifullah, E., 2019. Studi iknofosil untuk rekonstruksi model sistem pengendapan sedimen berumur Miosen Cekungan Kutai, Samarinda dan sekitarnya, Kalimantan Timur [Dissertation]. Institut Teknologi Bandung. (Text in Indonesia).

Arifullah, E., Zaim, Y., Aswan and Djuhaeni, 2020. A brief note on the latest ichnological studies. Proceedings The $45^{\text {th }}$ IAGI Annual Convention, pp. 227-233.

Bachtiar, A., 2004. Kerangka stratigrafi sekuen dan karakter batuan induk Miosen Awal di Cekungan Kutai Hilir, Kalimantan Timur [Dissertation]. Institut Teknologi Bandung. (Text in Indonesia).

Bromley, R.G., 1967. Some observations on burrows of thalassinidean Crustacea in chalk hardgrounds. Q. J. Geol. Soc. London, v. 123 , pp. 157-177.

Bromley, R.G., 1996. Trace fossils: biology, taphonomy and applications. Springer Science+Business Media B.V.

Dalrymple, R.W. and Choi, K., 2007. Morphologic and facies trends through the fluvial-marine transition in tidedominated depositional systems: A schematic framework for environmental and sequencestratigraphic interpretation. Earth Science Review, v. 81, pp. 135-174.

Howard, J.D., 1978. Sedimentology and trace fossils. In: P.M. Basan (ed.), Trace fossil concepts, SEPM Short Course, v. 5, pp. 13-45.

Kotake, N., 1991. Packing process for the filling material in Chondrites. Ichnos, v. 1, pp. 277-287.

Miller, W., 2007. Complex trace fossils. In: W. Miller (ed.), Trace fossils: concepts, problems, prospects, Elsevier B.V, pp. 458-465.

Pickerill, R.K. and Narbonne, G.M., 1995. Composite and compound ichnotaxa: A case example from the Ordovician of Quebec, Eastern Canada. Ichnos, v. 4, pp. 53-69.

Pemberton, G.S. and Frey, R.W., 1982. Trace fossil nomenclature and the Planolites-Paleophycus dilemma. Journal of Paleontology, v. 56, pp. 843-881.

Pemberton, G.S., Spila, M., Pulham, A.J., Saunders, T., MacEachern, J.A., Robbins, D. and Sinclair, I.K., 2001. 
Ichnology \& sedimentology of shallow to marginal marine systems, Short Course Notes, Geological Association of Canada, v. 15, pp. 105-136.

Pollard, J.E., Goldring, R., and Buck, S.G., 1993. Ichnofabrics containing Ophiomorpha: Significance in shallowwater facies interpretation. Journal of the Geological Society, London, v. 150, pp. 149-164.
Rhoads, D.C. and Young, D.K., 1970. The influence of deposit-feeding organisms on sediment stability and community trophic structure. Journal of Marine Research, v. 28, pp. 150178.

Supriatna, S., 1995. Peta Geologi Lembar Samarinda. (Pusat Penelitian dan Pengembangan Geologi).

Taylor, A., Goldring, R., and Gowland, S., 2003. Analysis and application of ichnofabrics. Earth Science Review, v. 60, pp. 227-259. 